\title{
Sensitization study of dogs with atopic dermatitis in the central region of Rio Grande do Sul
}

\author{
[Estudo da sensibilização de cães com dermatite atópica na região central \\ do Rio Grande do Sul]

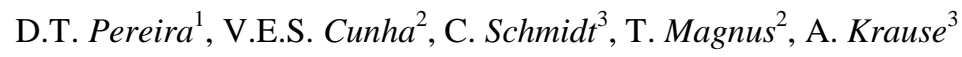 \\ ${ }^{1}$ Aluna de pós-graduação - Universidade Federal de Santa Maria - UFSM - Santa Maria, RS \\ ${ }^{2}$ Autônomo \\ ${ }^{3}$ Centro de Ciências Rurais - Universidade Federal de Santa Maria - UFSM - Santa Maria, RS
}

\begin{abstract}
Canine atopic dermatitis (CAD) is a common dermatosis, defined as a genetic-related disease which predisposes to skin inflammation and pruritus, associated to a IgE-specific response in most of cases. Clinical diagnosis may be later complemented by skin allergy and/or serological tests. The aim of these tests is to identify possible allergens in order to enable the clinicians to select candidate antigens for allergen specific immunotherapy. In the present study 58 CAD positive animals were tested. All were submitted to the intradermal test (IDT) and screened for the presence of antibodies against different antigens using ELISA. The obtained results show a high prevalence of sensitization among the tested dogs to house dust mites and to pollen of $C$. dactylon. With this work it was possible to identify the main allergens involved in immunological response of dogs with CAD living in central area of Rio Grande do Sul.
\end{abstract}

Keywords: intradermal test, serological test, house dust mites, storage mites, Cynodon dactylon

\section{RESUMO}

A dermatite atópica canina (DAC) é uma dermatose comum, definida como doença de cunho genético que predispõe à inflamação e ao prurido cutâneo, associados à resposta IgE específica na maior parte dos casos. O diagnóstico da DAC é clínico e pode ser posteriormente complementado por testes alérgicos cutâneos elou sorológicos. O objetivo desses testes é identificar possíveis alérgenos e, com isso, possibilitar ao clínico a seleção de antígenos candidatos para a imunoterapia alérgeno-específica. No presente estudo, foram testados 58 animais diagnosticados para DAC. Todos os animais foram submetidos ao teste cutâneo intradérmico (TID), e amostras de sangue foram coletadas para a realização de testes sorológicos. Os resultados obtidos demonstraram elevada prevalência de sensibilização aos ácaros domiciliares e ao pólen da gramínea $C$. dactylon nos cães testados. Com este trabalho, foi possivel identificar os principais alérgenos envolvidos na resposta imunológica de cães atópicos residentes na região central do Rio Grande do Sul.

Palavras-chave: teste intradérmico, teste sorológico, ácaros da poeira domiciliar, ácaros de produtos armazenados, Cynodon dactylon

\section{INTRODUCTION}

Canine atopic dermatitis (CAD) is a common and chronic dermopathy defined as a geneticrelated and multifactorial disease. CAD predisposes to inflammation and pruritus of the skin, which are associated in most cases to an allergen-specific immunoglobulin of IgE class (Olivry et al. 2010). The main allergens involved in CAD pathogenesis are house dust and store mites (HM); fungal spores; pollen of grass, trees and bushes and epidermal antigens (Hill; Deboer 2001).

Recebido em 26 de fevereiro de 2015

Aceito em 7 de agosto de 2015

E-mail: desydere@gmail.com 
Clinical diagnostic of CAD is relatively simple and according to Favrot et al. (2010), can be established with $42 \%$ sensibility and $94 \%$ specificity for dogs presenting six of seven criteria and $77 \%$ sensibility and $83 \%$ specificity when at least five of including criteria are fulfilled. The diagnostic criteria are: (1) appearance of signals before three years of age; (2) indoor dog; (3) primary pruritus (4) extremities of the thoracic limbs affected; (5) lesions in the concave region of the ears; (6) absence of lesions in ear borders; (7) absence of lesions in dorsolumbar region. Other differential diagnostics must always be eliminated.

The treatment of dogs affected by CAD is based on attempts to re-establish the skin barrier by rehydration, and moreover reduce inflammation and pruritus. In this direction, corticosteroids and other anti-inflammatory, immunomodulatory and immunosuppressive drugs are currently used. In order to reduce the use of all those drugs, allergen-specific immunotherapy can be added to the therapeutic schedule (Deboer; Marsella 2001).

Allergy tests are useful to identify the IgEmediated hypersensitivity and to select candidate allergens for allergen-specific immunotherapy in dogs with CAD. It is extremely important to establish the sensitivity profile of the patient before starting the treatment (Olivry et al. 2005). In current literature, there is no published information regarding the sensitivity profile of Brazilian dogs with CAD. Cunha et al. (2012) detected the presence of antibodies against home mites, such as Dermatophagoides farinae e Blomia tropicalis in serum samples of CAD dogs living in Rio de Janeiro.

The aim of this study was to determine the sensitization profile of dogs diagnosed for CAD and living in Rio Grande do Sul State, by two independent methods: Intradermal tests (IDT) and antibody detection in serum by EnzymeLinked Immunosorbent Assay (ELISA).

\section{MATERIAL AND METHODS}

Fifty eight dogs of different breeds, with ages from six months to eight years, diagnosed for atopic dermatitis, according to established criteria (Favrot et al., 2010). Before IDT was carried, all dogs underwent clinical and dermatologic examination and were treated for bacterial infections, when necessary, before the intradermal tests. Blood collection was performed in order to obtain sera for antibody detection.

This study was approved by the ethics and animal welfare commission of the Federal University of Santa Maria (process nr. 070/2014), and all procedures followed the Brazilian Guidelines for Care and Use of Animals for Scientific and Didactic Purposes, of the Brazilian Council for Control of Animal Experimentation - CONCEA. All owners signed an informed consent before the patients were enrolled in the Project.

All dogs were submitted to IDTs, which tested allergenic extracts of Dermatophagoides pteronyssinus, Dermatophagoides farinae, Blomia tropicalis, Cynodon dactylon e Paspalum notatum, kindly provided by FDA Allergenic (Rio de Janeiro - Brazil). Before performing the IDT, the dogs receiving treatment had the administration interrupted in order to avoid possible interferences, according to Olivry et al. (2013). Dogs were shaved in the lateral thoracic region with a number 40 razor blade. After skin preparation, $0,05 \mathrm{ml}$ of extracts and control solutions were injected intradermally, at a $2 \mathrm{~cm}$ distance from different tests. Needles were $0,25 \mathrm{~mm} \times 6 \mathrm{~mm}$, and connected to $0,3 \mathrm{ml}$ syringes (BD Ultra-FineTM II). Skin reactions were measured 15 minutes after inoculation, and the diameter of reactions was calculated by the average between the largest diameter and its perpendicular. In order to be considered positive, a given reaction must be larger than the average measure between positive (PC) and negative controls (NC) (Scott et al., 2001).

Five $\mathrm{ml}$ of venous blood were withdrawn from jugular or cephalic veins. Sera was separated after room temperature clot retraction and centrifugation for $20 \mathrm{~min}$ at 7,500rpm and stored at $-20^{\circ} \mathrm{C}$. Detection of antibodies against a series of allergens was carried in serum of 30 dogs, using an indirect ELISA, which was developed by the Research and Revelopment Department of FDA Allergenic and in other 28 samples the antibodies detection was performed using a commercial ELISA kit (Pet ELISA® ALERGOVET). 
FDA ELISA included antigens of $D$. pteronyssinus, D. farinae, $B$. tropicalis and Tyrophagus putrescentiae. Initially, 96 well plates were sensitized with a dilution of the allergens $(100 \mu 1 /$ well $)$, incubated overnight at

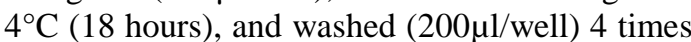
with PBS -Tween $200,01 \%$, followed by two more washes with PBS. In order to avoid unspecific binding, 200 $\mu 1$ of a blocking solution (bovine albumin $1 \%$ in PBS) were pipetted into the plate and incubated at $37^{\circ} \mathrm{C}$ for $1 \mathrm{~h}: 30 \mathrm{~min}$. After blocking, the plates were washed again with PBS and $100 \mu$ l of two dilutions of serum samples (1:10 and 1:30) were given to the wells (according to previous validation) and in quadruplicates. Negative controls (BSA1\%) were pipetted into the wells from rows 1 and 12. After two hours incubation at $37^{\circ} \mathrm{C}$, the plates were washed and $100 \mu 1$ of secondary antibody polyclonal (goat origin) anti-dog IgE, peroxidase conjugated diluted 1:8000 in PBS-BSA was pipetted into each well. Plates were incubated at $37^{\circ} \mathrm{C}$ for two hours and washed as previously described. Substrate peroxidase (TMB peroxidase) was given and after 20 minutes the reaction was stopped with phosphoric acid $1 \mathrm{M}$. The reaction was red by spectrophotometry at $450 \mathrm{~nm}$.

In the tests carried out for the 28 dogs, using the commercial kit (Pet ELISA® - ALERGOVET), together with the extracts of $D$. pteronyssinus, $D$. farinae, B. tropicalis and $T$. putrescentiae, the antigens of the mite sirus, Lepidoglyphus destructor, Cynodon. dactylon, Phleum, Oat, Lolium, Artemisia vulgaris, Chaenopodium spp, Parietaria judaica, Ambrosía elatior, Betulacea and Quercus were included. This test uses a similar protocol to the one described for the tests developed by FDA Allergenic, with exception of the secondary antibody, which is oligoclonal, and composed by three specific monoclonal antibodies against the canine IgE (Olygo. $3 \mathrm{mAb})$.

In order to evaluate the correspondence of results for sensitization to D. pteronyssinus, D. farinae, $B$. tropicalis and $C$. dactylon, antigens, tested in both methods, we used Kappa statistics, with the SPSS software. The significance level was $5 \%$.

\section{RESULTS}

Of the 58 animals tested by IDT, $25(43,1 \%)$ were negative. Among 33 positive animals, 16 $(27,6 \%)$ were positive only against one antigen and considered monosensitized (MS). 17 $(29,3 \%)$ were positive to one or more antigens tested and, in those cases, were considered polysensitized (PS). Most of polysensitized animals were positive to mites and grass $(64,7 \%)$; sensibility only to mites was seen in $29,9 \%$ of dogs and one dog $(5,9 \%)$ was positive for more than one grass antigens. Sensitization distribution is shown in Table 1.

Table 1. Relationship between monosensitization to antigens in intradermal and serological tests

\begin{tabular}{lcc}
\hline \multicolumn{1}{c}{ Antigen } & $\begin{array}{c}\mathrm{IDT}^{* * *}(16 \\
\text { animals})\end{array}$ & $\begin{array}{c}\mathrm{ELISA}^{* * * *}(9 \\
\text { animals })\end{array}$ \\
\hline Mites & $62,5 \%(10 / 16)$ & $66,7 \%(6 / 9)$ \\
- B. tropicalis & $50 \%(5 / 10)$ & ---- \\
- D. farinae & $30 \%(3 / 10)$ & $83,3 \%(5 / 6)$ \\
- D. pteronyssinus & $20 \%(2 / 10)$ & ---- \\
- T. putrescentiae & ---- & $16,7 \%(1 / 6)$ \\
Grass pollen & $37,5 \%(6 / 16)$ & $33,3 \%(3 / 9)$ \\
- C. dactylon & $83,3 \%(5 / 6)$ & $66,7 \%(2 / 3)$ \\
- P. notatum & $16,7 \%(1 / 6)$ & ---- \\
- A. vulgaris & ----- & $33,3 \%(1 / 3)$ \\
\hline "Monosensitization; ${ }^{* *}$ Intradermal test; ${ }^{* * *}$ Serological test
\end{tabular}

The highest sensitization detected on IDT was seen for the following antigens: B. tropicalis 48,5\% (16/33), C. dactylon 42,4\% (14/33) and $D$. farinae $33,33 \%(11 / 33)$.

In regard to serological tests, 30 animals' samples were tested by ELISA - FDA Allergenic and 28 by Pet ELISA ${ }^{\circledR}$ - ALERGOVET. In these tests, $22(37,9 \%)$ dog serum samples were negative, nine $(15,7 \%)$ were MS (Table 1) and $27(46,6 \%)$ were PS. Of these, 22 dogs $(81,5 \%)$ were PS to mites and five $(18,5 \%)$ PS to grass. There was no mixed PS, i.e. sensitization to mites and grass in the same sample.

On IDT the antigens which induced the strongest reaction (highest sensitivity) were: $B$. tropicalis 48,5\% (16/33), C. dactylon 42,4\% (14/33) and $D$. farinae $33,33 \%$ (11/33); ELISA results showed the highest sensitization rate for $D$. farinae, $86,5 \%$ (32/37), followed by A. sirus $64,7 \%$ (11/17), T. putrescentiae 56,8\% (21/37), B. tropicalis $48,6 \%(18 / 37)$ and $41,2 \%(7 / 17)$ de positivity to $C$. dactylon (Table 2 ). 
Table 2. Sensitivity perceptual to the most relevant antigens tested

\begin{tabular}{lcc} 
Antigen & $\mathrm{IDT}^{*}$ & $\mathrm{ELISA}^{* *}$ \\
$\mathrm{n}(\%)$ & $\mathrm{n}(\%)$ \\
\hline D. pteronyssinus & $8 / 33(24,2 \%)$ & $11 / 37(29,7 \%)$ \\
D. farinae & $11 / 33(33,3 \%)$ & $32 / 37(86,5 \%)$ \\
B. tropicalis & $16 / 33(48,5 \%)$ & $18 / 37(48,6 \%)$ \\
T. putrescentiae & ---- & $21 / 37(56,8 \%)$ \\
A. sirus & ---- & $11 / 17(64,7 \%)$ \\
L. destructor & ---- & $5 / 17(29,4 \%)$ \\
C. dactylon & $14 / 33(42,4 \%)$ & $7 / 17(41,2 \%)$ \\
P. notatum & $7 / 33(21,2 \%)$ & ---- \\
${ }^{*}$ Intradermal test; ${ }^{* *}$ Serological test. & &
\end{tabular}

Intradermal test; ${ }^{* *}$ Serological test.

In order to compare intradermal and serological test results, we used Kappa agreement analysis for D. pteronyssinus, D. farinae, B. tropicalis and $C$. dactylon antigens, and no correlation could be demonstrated, Table 3 .

Table 3. Agreement Kappa Analysis of antigens tested by intradermal and serological tests

\begin{tabular}{lcc}
\hline Antigen & Kappa & $\mathrm{p}$ value \\
\hline D. pteronyssinus & 0.06 & 0.639 \\
D. farinae & 0.06 & 0.531 \\
B. tropicalis & 0.169 & 0.169 \\
C. dactylon & -0.1 & Non applicable \\
\hline
\end{tabular}

The antigens $D$. pteronyssinus, L. destructor and $P$. notatum were responsible for sensitization in at least $20 \%$ of the animals tested (with no regard to the method) (Table 2), and the other tested antigens were less frequent as follow: A. vulgaris 17,6\% (3/17), A. elatior and Betulacea 11,8\% (2/17), Phleum, Aveia, Lolium, Chaenopodium spp and Quercus being positive in only one of the 17 sensitized dogs $(5,9 \%)$; no sensitivity was seen in dogs to $P$. judaica.

\section{DISCUSSION}

The negative results rate of $43,1 \%$ obtained with the IDTs could be explained by the absence of relevant antigens, low sensitivity for the test, or by a condition called canine atopic like dermatitis, in which dogs with clinical characteristics of CAD do not present antibodies of IgE class detected (Halliwell 2006).

Among the positive animals, most presented polysensitization. In humans, this is also the most common condition (Calderon et al. 2012). PS to different species of CAD was more frequent; however, it was not possible to conclude if this situation occurred due to the exposition to different species of allergens or because of cross reactions. In concern of IDT, Buckley et al. (2013) showed the presence of cross reactions between phylogenetically similar organisms, possibly because they could share the same allergenic molecules in each mite family, such as among Dermatophagoides.

The most expressive allergens found in MS animals were $D$. farinae, $B$. tropicalis and $C$. dactylon, $D$. farinae and B. tropicalis are already described as important allergens for Brazilian dogs (Cunha et al., 2012). However, the importance of $C$. dactylon has not been proven for Brazilian dogs so far, although this species is well adapted to warm climate regions and is considered an important allergen for humans. C dactylon can be found in the entire Brazilian territory (Vieira 2012).

D. farinae is recognized as the main allergen in CAD throughout the world. According to Thomas (2010), this mite is present in all continents and, for this reason, highly represented in several studies to detect sensitization in allergic dogs. Such studies have been carried out for over 20 years (Sture et al., 1995; Saridomichelakis et al., 1999; Farmaki et al. 2012). Saridomichelakis and colleagues (1999) investigated $91 \mathrm{dogs}$ with CAD in Greece and found $84,6 \%$ dogs positive for domestic mites (D. farinae 70,3\% and A. sirus 48,4\%). In Australia, Mueller et al. (2000) described 34\% 
dogs positive to $D$. farinae. In 2002, a French study emphasized the importance of $D$. farinae, sensitivity, when $90 \%$ of 150 dogs screened with IDT were positive. Of these, $57 \%$ were MS, and it was also seen that $30 \%$ of dogs were sensitized for A. sirus and T. putrescentiae (Bensignor; Carlotti 2002). In Thailand, in a 114 dogs study, $74 \%$ were positive to $D$. farinae (Chanthick et al. 2008).

In Brazil, the importance of D. farinae was demonstrated in $28 \%$ of $25 \mathrm{dogs}$ tested with IDT. This study reported the highest positivity to $T$. putrescentiae and L. destructor, with $40 \%$ positive reactions for each allergen, and of $12 \%$ for D. pteronyssinus and B. tropicalis (Cunha et al. 2007).

According to several authors, the relevance of a positive reaction to house mites is well demonstrated. Interestingly, our study showed at least $40 \%$ positivity for pollen of $C$. dactylon, in dogs tested with IDT and ELISA. In Brazil, this grass is associated with allergic reactions in humans and the sensitization can occur isolated or combined with other perennial allergens, such as house dust mites (genus Dermatophagoides) and animal epithelium or arthropod proteins (Taketomi et al. 2006). Human allergologists emphasize that in the Southern Brazilian state that it is very important that the $C$. dactylon be added to the allergic test, in order to address the specific immunotherapy in positive patients (Rosário Filho, 2012).

Both tests were used to allow the establishment of a sensitization profile of $58 \mathrm{dogs}$ enrolled in the present study. When the statistical Kappa analysis was performed, a correlation between the results from IDT and ELISA could not be found. As described in literature, IDT and ELISA are different tests, where IDT detects specific $\operatorname{IgE}$ bound to mast cells in the skin and the serologic test detects free IgE molecules present in the blood (Foster et al. 2003).

\section{CONCLUSION}

House mites, represented by $D$. farinae, $B$. tropicali and $T$. putrescentiae species and grass pollen $C$. dactylon are the main allergen sources for dogs with CAD in the central region of Rio Grande do Sul. No statistical correlation was observed between intradermal and serological tests performed in this study.

\section{REFERENCES}

BENSIGNOR, E.; CARLOTTI, D.N. Sensitivity patterns to house dust mites and forage mites in atopic dogs: 150 cases. Vet. Dermatol., v.13, p.39-44, 2002.

BUCKLEY, L.; SCMIDT, V.; McEWAN, N. et al. Cross-reaction and co-sensitization among related and unrelated allergens in canine intradermal tests. Vet. Dermatol., v.24, p.422427, 2013.

CALDERON, M.A.; COX, L.; CASALE, T.B. $e t$ al. Multiple-allergen and single-allergen immunotherapy strategies in polysensitized patients: Looking at the published evidence. $J$. Allergy Clin. Immunol., v.129, p.929-934, 2012.

CHANTHICK, C.; ANAMANM, S.; BAUTHET, K. The prevalence of positive intradermal allergy tests in 114 dogs with atopic dermatitis in the Bangkok metropolis, Thailand. Vet. Immunol. Immunopathol., v.126, p.256-262, 2008.

CUNHA, V.E.S.; SILVA, M.H.; FACCINI, J.L.H. Serological identification of house dust mite allergens in dogs with atopic dermatitis. Pesqui. Vet. Bras., v.32, p.917-921, 2012.

CUNHA, V.E.S.; HAHNSTADT, R.L.; SOARES, A.M.B.S.; FACCIN, J.L.H. Evaluation of skin sensitivity in $\operatorname{dog} s$ bearing allergic dermatitis to standardized allergenic extract of house dust and storage mites. Pesqui. Vet. Bras., v.27, p.341-344, 2007.

DEBOER, D.J.; MARSELLA, R. The ACVD task force on canine atopic dermatitis (XII): the relationship of cutaneus infections to the patogenesis and clinical course of canine atopic dermatitis. Vet. Immunol. Immunopathol., v.81, p.239-249, 2001.

FARMAKI, R.; SARIDOMICHELAKIS, M.N.; LEONTIDES, L. et al. Dust mite species in the households of mite-sensitive dogs with atopic dermatitis. Vet. Dermatol., v.23, p.222-e45, 2012.

FAVROT, C.; STEFFAN, J.; SEEWAL, W. et al. A prospective study on the clinical features of chronic canine atopic dermatitis and its diagnosis. Vet. Dermatol., v.21, p.23-30, 2010. 
FOSTER, A.P.; LITTLEWOOD, J.D.; WEBB, P et al. Comparison of intradermal and serum testing for allergen-specific IgE using a FceRl $\alpha$ based assay in atopic dogs in the UK. Vet. Immunol. Immunopathol., v.93, p.51-60, 2003.

HALLIWELL, R. Revised nomenclature for veterinary allergy. Vet. Immunol. Immunopathol., v.114, p.207-208, 2006.

HILLIER, A.; DEBOER, D.J. The ACVD task force on canine atopic dermatitis (XVII): intradermal testing. Vet. Immunol. Immunopathol., v.81, p.289-304, 2001.

MUELLER, R.S.; BETTENAY, S.V.; TIDEMAN, L. Aero-allergens in canine atopic dermatitis in southeastern Australia based on 1000 intradermal skin tests. Aust. Vet. J., v.78, p.392-399, 2000.

OLIVRY, T.; SARIDOMICHELAKIS, M, et al. Evidence-based guidelines for anti-allergic drug withdrawal times before allergen-specific intradermal and IgE serological tests in dogs. Vet. Dermatol., v.24, p. 225-e49, 2013.

OLIVRY, T.; DeBOER, D.J.; FAVROT, C et al. Treatment of canine atopic dermatitis: 2010 clinical practice guidelines from the international task force on canine atopic dermatitis. Vet. Dermatol., v.21, p. 233-248, 2010.

OLIVRY, T.; JACKSON, H.A., MURPHY, K.M. et al. Evaluation of a point-of-care immunodot assay for predicting results of allergen-specific intradermal and immunoglobulin E serological tests. Vet. Dermatol., v.16, p.117-120, 2005.
ROSÁRIO FILHO, N.A. Alergia ao pólen de gramíneas: "back to the future". Rev. Bras. Aler. Imunopatol., v.35, p.82-84, 2012.

SARIDOMICHELAKIS, M.N.; KOUTINAS, A.F.; GIOULEKAS, D et al. Canine atopic dermatitis in Greece: clinical observations and the prevalence of positive intradermal test reactions in 91 spontaneous cases. Vet. Immunol. Immunopathol., v,69, p.61-73, 1999.

SCOTT, D.W.; MULLER, JR. W.H.; GRIFFIN, C. E. Skin immune system and allergic skin diseases. In: Small animal dermatology. 6.ed. Philadelphia: Elsevier, 2001. chap. 8, p.543-666.

SPSS for Windows. Version 17.0. Chicago, SPSS Inc, 2007.

STURE, G.H. Canine atopic disease: the prevalence of positive intradermal skin tests at two sites in the north and south of Great Britain. Vet. Immunol. Immunopathol., v.44, p.293-308, 1995.

TAKETOMI, E.A.; SOPELETE, M.C.; MOREIRA, P.F.S.; VIEIRA, F.A.M. Pollen allergic disease: pollens and its major allergens. Rev. Bras. Otorrinolaringol., v.72, p.562-567, 2006.

THOMAS, W.R. Geography of house dust mite allergens. Asian Pac. J. Allergy. Immunol., v.28, p.211-224, 2010.

VIEIRA, F.M. Gramíneas tropicais alergênicas: Cynodon dactylon e Paspalum notatum - uma visão para o trópico brasileiro. Rev. Bras. Alerg. Imunopatol., v.35, p.40-41, 2012. 